4. Ермолаев А. П., Халдеева О. К. Философия граничного существования. Концепция «граничности» в формировании художественного сознания в дизайне. Пропедевтика визуального мышления: учебное пособие. - М.: БуксМАрт, 2020. 188 с.

5. Ерышева Е. А., Демидова Т. А. Композиционно-творческий «тренинг» как основа формирования концептуального мышления // Композиционные чтения имени А. Коротковского: Материалы Международной научно-методической конференции. - Екатеринбург: Архитектон, 2005. С. 56-61.

6. Росси, А. Научная биография / Пер. с ит. - М.: Strelka Press, 2015. 176 c.

7. Города. Архитектурный фестиваль. - Екатеринбург: TATLIN, 2015. 392 с.

8. Ревзин, Г. И. Как устроен город: 36 эссе по философии урбанистики. - M.: Strelka Press, 2019. 270 c.

9. Негорошкова, Ю., Швинк, Н. «Дорогой дядя Саша» // Казань. 2005. № 7/8 (99). С. 120-125.

10. Новичков И. А., Романченко А. С., Набиева Н. Р. Проектная деятельность у школьников и студентов как инструмент формирования навыков для самообразования // НБИКС: Наука.Технологии. 2017. №2. Т.2. С. 273-296.

11. Рязанов И. А., Шаров М. О. Проектная деятельность и еѐ реализация в образовательных учреждениях: обзор на основе опыта применения в рамках мыследеятельностной педагогики // НБИКС: Наука.Технологии. 2017. №2. T.2. С 256-272.

12. Рябов Н. Ф., Грачев П. В. Проектно-игровые практики в процессуальной организации образовательного пространства на примере детской архитектурно-дизайнерской школы «ДАШКА» КГАСУ // Известия КГАСУ. 2021. № 3 (57). С. 61-72. DOI: 10.52409/20731523_2021_3_61.

13. Серикова В. Интервью с В. Полуниным: «К клоунам нужен особый подход - как к сумасшедшим» // Имена. 2008. № 12. С. 130-140.

14. Фаулз, Д. Аристос / Пер. с англ. - М.: АСТ: АСТ Москва, 2008. 347 с.

15. Ямпольский, М. Б. Пространственная история. Три текста об истории. - СПб.: Книжные мастерские; Мастерская «Сеанс», 2013. 344 с.

\title{
Сусуйкина А.А. \\ Готовность педагогов к осуществлению сопровождения обучающихся 10-11 классов при организации проектной деятельности
}

МБОУ «Лицей №165»

(Россия, Нижний Новгород)

doi: 10.18411/trnio-01-2022-156

\section{Аннотация}

В данной статье рассматривается вопрос о проектной деятельности обучающихся 1011 классов, об особенностях содержания и способах организации педагогического сопровождения процесса формирования проектной компетентности учащихся старших классов. Грамотно организованное педагогическое сопровождение проектной деятельности обучающихся способствует формированию проектной компетентности, саморазвитию учащихся, повышению культуры общения и опыта публичных выступлений, развитию творческих способностей личности, мотивации к получению знаний и дополнительной продуктивности образовании.

Ключевые слова: проектная деятельность; индивидуальный проект; организация проектной деятельности.

\section{Abstract}

This article discusses the issue of project activities of students in grades 10-11, the features of the content and methods of organizing pedagogical support for the process of forming project competence of high school students. Well-organized pedagogical support of students ' project activities contributes to the formation of project competence, self-development of students, improving the culture of communication and experience of public speaking, the development of creative abilities of the individual, motivation to acquire knowledge and additional productivity.

Keywords: project activity; individual project; organization of project activity.

Многое изменилось в системе образования за последние годы. В частности, другими стали образовательные стандарты, востребованная страной номенклатура специалистов, 
значительно возросли требования к уровню и качеству их подготовки, поскольку кадры должны соответствовать характеру и современным задачам совершающихся в России экономической и других реформ.

В условиях развития инноваций востребованы выпускники общеобразовательных учреждений, обладающие навыками познавательной, учебно-исследовательской и проектной деятельности, способностью и готовностью к самостоятельному поиску методов решения практических задач, применению различных методов познания. Указанные требования к результатам обучения представлены в Федеральном государственном образовательном стандарте среднего общего образования в блоке познавательных универсальных учебных действий и обусловливают необходимость развития индивидуальной проектноисследовательской деятельности.

Метод проектов еще лет десять назад стоял в ряду инновационных методов. Сегодня проектная деятельность прочно вошла в образовательный процесс на уровне как урочной, так и внеурочной деятельности, а также стала одной из обязательных форм итоговой аттестации. Так, с 2020-2021 учебного года в обучение 10-11 классов (ФГОС СОО) введен новый предмет «Индивидуальный проект» - это отдельный курс, в результате изучения которого от старшеклассников ожидается создание межпредметного и полидисциплинарного проекта. Программный материал отражает современные запросы общества и государства к построению образовательного процесса: деятельностный характер обучения, ориентир на метапредметные результаты, развитие информационной грамотности, в том числе навыков владения ИКТ при освоении образовательных программ. Предполагается, что у каждого выпускника школы в аттестате будет стоять отметка за индивидуальный проект и будет указана его тематика. Вести курс «Индивидуальный проект» может любой учитель.

Почему вводится данный предмет? Главной целью изучения метапредметного курса «Индивидуальный проект» является формирование проектной компетентности обучающихся, осваивающих основную образовательную программу среднего общего образования. Проектная компетентность определяется как проектная деятельность и свойственные ей компетенции. Рассматривая подход И.А. Зимней по выделению трех основных групп компетенций, в качестве исходных для проектной компетентности можно рассмотреть:

- компетенции относящиеся к человеку, как к личности, субъекту деятельности, общения, - компетенции саморегулирования, саморазвития, смысл жизни;

- компетенции, относящиеся к социальному взаимодействию человека и социальной среды, - социальная мобильность и социальная активность, компетенция в общении;

- компетенции, относящиеся к деятельности человека, компетенции планирования, проектирования, моделирования, прогнозирования, ориентация в разных видах деятельности.

Специфика проявления всех этих процессов в ходе формирования проектной компетентности у старшеклассников связана прежде всего, с особенностями проектной деятельности.

Сформированная проектная компетентность позволит получить новое качество образования, объединив прагматизм проектов, исследовательскую культуру и огромное количество возможностей. Доктор педагогических наук МПГУ Т. М. Ковалева утверждает, что исследовательская деятельность перестает быть социально-значимой, она становится редким явлением, привлекает действительно исследовательски-одаренных людей. Как же это сочетается с проектами? Все проекты носят прикладной характер, они становятся средством для получения проектного практического продукта. Но понять, насколько хорош и востребован продукт, невозможно без проведения хотя бы минимального исследования. Поэтому каждый проект внутри обязательно содержит исследование, а большое или малое зависит от целей и задач проекта. 
Способность старшеклассников строить жизненные планы - моделировать образ будущего, способность трудиться для воплощения планов жизнь, понимание важности этой деятельности для себя и окружающих, способность соотносить свои интересы с интересами других людей - специфика возраста, связанная с готовностью осуществлять проектную деятельность.

ОБУЧАЮЩИЕСЯ - ГОТОВЫ, есть осознание в необходимости, НО ни в одной из разработанных методик, не предложена модель формирования проектной компетентности учащихся старших классов, которая могла бы быть жизнеспособной, результативной в условиях образовательного пространства современной школы.

Анализ ситуации позволяет выявить ряд противоречий.

- На социально-педагогическом уровне: между изменившимися требованиями современного общества к существующей системе подготовки учащихся старших классов и реальной ситуацией в вопросе сформированное у выпускника основных компетенций, необходимых для осознанного выбора профессии и социальной адаптации в обществе.

- На научно-теоретическом уровне: между необходимостью формирования проектной компетентности обучающихся старших классов общеобразовательной школы и недостаточной разработанностью научного обеспечения исследуемого явления.

- На методико-технологическом уровне: между объективной потребностью практики в методическом обеспечении формирования проектных и исследовательских умений учащихся старших классов и недостаточной разработанностью содержательно-методического сопровождения рассматриваемого процесса.

Данные противоречия говорят о необходимости обоснования и разработки особенностей содержания и способов организации педагогического сопровождения процесса формирования проектной компетентности учащихся старших классов.

Требуется спроектировать компоненты:

— образовательного процесса, основанного на использовании проектной формы учебной деятельности на уроке и во внеурочное время;

- условий реализации: кадровых (обеспечение соответствующим требованиям проектной деятельности компетентности учителей), информационных (качество программно-методических и информационных ресурсов, представленных в виде организационно-нормативных документов), организационно-управленческих (система управления проектной деятельности), предполагающих наличие соответствующих локальных нормативных актов и регламентирующих процедур, распределение зон ответственности участников образовательного процесса (между администрацией школы, педагогами), функционирование специально созданных структур для организации взаимодействия - проектных и творческих групп.

Особенно кадровых.

В основе системы проектной деятельности с обучающимися 10-11 классов лежит коллективный педагогический труд - только в процессе совместных усилий могут быть достигнуты метапредметные результаты обучения при условии хорошего взаимопонимания между участниками процесса реализации проектного обучения. Достижение положительных результатов при использовании метода проектов возможно, если проектная деятельность с самого начала правильно организована, выбрана удачная тематика проектных заданий, эффективные методы и организационные формы их реализации, определены реальные сроки выполнения, создана необходимая учебно-материальная база, осуществляется 
систематический контроль над выполнением проектов со стороны учителя. Ко всем этим действиям необходимо подготовить учителей.

Необходимо подчеркнуть, что организация реализации проектной деятельности обучающихся требует единого подхода к проектированию рабочей программы по предмету, уроков ориентированных на реализацию проектной деятельности, организацию внеурочной деятельности. Учитель в проектной деятельности - тьютор, координатор, режиссер проекта. Проектная деятельность - это своеобразный педагогический инструмент, с помощью которого учитель может создавать ситуацию успеха, как личного, так и коллективного.

От учителя требуется умение грамотно создать условия для разработки, реализации и защиты проекта, не вмешиваясь в процесс осуществления обучающимся проектной деятельности, но выполняя три основных функции:

1. обеспечение разработки индивидуального проектного маршрута обучающегося и сопровождения процесса индивидуализации и образовательной рефлексии (позиция тьютора);

2. консультационная поддержка в соответствии с предметным содержанием проекта (позиция консультанта);

3. диагностика развития проектной компетентности обучающегося на основе сравнения актуального уровня сформированности проектных действий с его предыдущими достижениями, оценка качества проектного продукта, полученного обучающимся в процессе осуществления проектной деятельности (позиция эксперта).

Педагогический работник, должен уметь организовывать, сопровождать, реализовывать педагогическое оценивание проектной и учебно-исследовательской деятельности обучающихся, выполнения ими индивидуального проекта, принять и реализовывать тьюторскую позицию.

Учителю для успешного сопровождения проектной и исследовательской деятельности школьников необходимо учитывать возрастные особенности развития, предлагая те или иные темы работ, необходимо знать основы методики, принципы и сущность проектного и исследовательского обучения. Учителю необходимо наличие ясной и простой критериальной системы оценки итогового результата работы по проекту. Каждая образовательная организация разрабатывает собственный план/ порядок/регламент проектной деятельности, отражая его, обычно, в «Положении о проектной деятельности».

Старшее поколение учителей-стажистов, получивших образование в педагогических институтах, такой работой не занималось. Чуть более молодые выпускники педагогических университетов кроме (или вместо) сдачи государственных экзаменов защищали дипломные работы. Правила написания таких работ везде были разными и далеко не всегда носили исследовательский характер. Совсем недавние выпускники в вузах могли прослушать соответствующие спецкурсы по проектной и исследовательской деятельности. Но опять же, далеко не всегда эти спецкурсы велись преподавателями, имеющими соответствующий опыт и квалификацию. Вывод: проблема готовности учителей к качественному выполнению задачи включения в структуру содержания образования в качестве обязательного элемента учебно-исследовательской и проектной работы остаётся пока не решённой.

Сложность организации работы над индивидуальным проектом в рамках учебного предмета связана как с режимом реализации ФГОС СОО, который дает право образовательной организации принимать решение о реализации этого предмета (несколько вариантов) и с отсутствием выбора УМК по данному вопросу.

Каким образом можно попытаться решить поставленную задачу? Подготовить учителей к организации индивидуального учебного проектирования, которое включает следующие аспекты, позволяющие получить необходимый результат с наименьшими затратами: 
- аксеологический - формирование ценностной позиции учителя по отношению к предоставляемой информации и к предполагаемому способу деятельности;

- методический - овладение новыми способами (технологиями, приемами, умениями) педагогической деятельности;

- информационный - получение, систематизация новой информации.

Подготовить учителей можно используя системно организованную методическую работу в образовательной организации. Целью такой деятельности будет формирование профессиональной среды, направленной на формирование и развитие профессиональной компетентности учителей.

Первоначально следует проанализировать готовность учителей к организации самостоятельной проектной деятельности обучающихся.

Затем - провести анкетирование педагогов для изучения педагогических достижений и затруднений при организации в реализации индивидуальных проектов обучающихся.

Мониторинг затруднений позволит внести изменения в методическую работу. Например, на основе выявленных проблем сформировать и организовать обучение учителей, рассматривая как внутренние, так и внешние ресурсы.

Так, можно предложить следующую программу спецкурса «Проектная деятельность», которая будет включать в себя следующие темы для изучения.

- $\quad$ Проектная деятельность как неотъемлемый компонент учебного процесса в условиях становления компетентностного подхода в образовании.

- Сущность и дидактические особенности метода проектов как педагогической технологии. Развитие мышления на уроке.

- Организация и реализация проектной деятельности в учебном процессе современной школы. Работа в команде при подготовке и реализации проекта.

- Использование вопросов в проектной деятельности.

- $\quad$ Разработка идеи проекта.

- Обучение с использованием проектов на основе информационных технологий.

- $\quad$ Поиск и отбор ресурсов для выполнения проекта.

- Анализ информации, аргументация и выводы в рамках проектной деятельности.

- $\quad$ Презентация и продвижение проекта.

- $\quad$ Групповые проекты.

- $\quad$ Экспертиза качества индивидуального проекта (на примере одного из учеников)

Очень важно представить в систематизированном виде всю информацию, касающуюся курса обучения, его содержания, организационных моментов. Занятия дадут возможность освоить теоретические основы проектной деятельности и будут транслироваться учителями обучающимся в единой форме.

На занятиях спецкурса, помимо традиционных педагогических методов (лекция, демонстрация, упражнения, обсуждение и др.), необходимо применять активные формы обучения, направленные на развитие у учителей творческого мышления и способности квалифицированно решать профессиональные задачи: анализ конкретной ситуации, «лабиринт действий», «интеллектуальная разминка», «мозговая атака», тематическая дискуссия, профессионально-дидактическая игра, метод «круглого стола» и т.д.

Для дальнейшей деятельности, при организации обучающих мероприятий, эффективнее всего - система проектных групп, а так же экспертных групп.

Необходимо предусмотреть формы методической работы для предотвращения возможных трудностей учителей в процессе организации, а так же при тьюторском 
сопровождении индивидуальной самостоятельной проектной деятельности обучающихся. Как коллективные (например, проблемные семинары, круглые столы, педагогические мастерские, творческие конкурсы), групповые (проектные команды, творческие группы, экспертный совет, методические объединения, тренинги, ролевые игры), так же индивидуальные (самообразование, индивидуальные консультации, разработка методических материалов, разбор педагогических ситуаций).

При реализации тьюторского сопровождения индивидуальной самостоятельной проектной деятельности обучающихся проводить своевременно мониторинг для определения эффективности и своевременной коррекции деятельности учителя.

Грамотно организованное педагогическое сопровождение проектной деятельности обучающихся будет способствовать саморазвитию учащихся, повышению культуры общения и опыта публичных выступлений, развитию творческих способностей личности, мотивации к получению знаний и дополнительной продуктивности образования.

Проблема формирования готовности учителей к проектной деятельности в школе еще требует дальнейшего изучения, поиска новых форм и методов работы, а также - разработки методического обеспечения данного направления.

$$
\text { *** }
$$

1. Зимняя И.А. Ключевые компетентности как результативно-целевая основа компетентностного подхода в образовании. М., 2004

2. Леонтович А.В., Саввичев А.С. Исследовательская и проектная работа школьников. 5-11 классы/ Под ред. А.В. Леонтовича. - 2-изд.- М.: ВАКО, 2016.- 160с. -(Современная школа: управление и воспитание).

3. Плетенева О.В., Бармина В.Я., А.Б. Макарова, В.В. Целикова Организация самостоятельной проектной деятельности обучающихся 8-9 классов . Учебно-методическое пособие /- Н.Новгород:НИРО, 2017

4. Плетенева О.В., и др. Потенциал проектно-дифференцированного обучения в достижении современных требований к результатам основного общего образования: материалы Международной научно-практической конференции - Н. Новгород: НИРО, 2016,

5. Плетенева О.В., и др Проектирование учебного процесса в ПДО: рабочая программа и учебное занятие. Методическое пособие /- Н.Новгород:НИРО, 2017

6. Яковлева Н.Ф. Проектная деятельность в образовательном учреждении [Электронный ресурс]: учеб. пособие. - 2-е изд., стер. - М.: ФЛИНТА, 2014.

7. Сараева, А. А. Проектная деятельность как необходимый компонент профессиональной подготовки будущего учителя / А. А. Сараева. - Текст : непосредственный // Актуальные вопросы современной педагогики : материалы I Междунар. науч. конф. (г. Уфа, июнь 2011 г.). — Уфа : Лето, 2011. — С. 114-117. —URL: https://moluch.ru/conf/ped/archive/18/803/ (дата обращения: 12.09.2021).

Татанов П.В., Чемерилова И.А. Кадровые проблемы на заводах и фабриках

ФГБОУ ВО «ЧГУ им. И.Н. Ульянова»

(Россия, Чебоксары)

doi: 10.18411/trnio-01-2022-157

\section{Аннотация}

В данной статье идет речь о кадровых проблемах на современных заводах и фабриках. Привлечь молодежь - задача номер один. Автором предлагаются решения для выхода из этой непростой ситуации.

Ключевые слова: молодежь, обучение, воспитание.

Abstract

This article deals with personnel problems in modern factories and factories. Attracting young people is the number one task. The author offers solutions to get out of this difficult situation.

Keywords: youth, training, education. 